\title{
PENINGKATAN KUALITAS PUPUK ORGANIK CAIR DARI LIMBAH CAIR PRODUKSI BIOGAS MENGGUNAKAN COMPOSTAR
}

\author{
Tri Retno Dyah L..$^{\text {(1) }}$ dan Srikandi ${ }^{2)}$ \\ ${ }^{1)}$ Bidang Industri dan Lingkungan - Pusat Aplikasi Isotop dan Radiasi, \\ Badan Tenaga Nuklir Nasional (PAIR - BATAN) \\ Jln. Lebak Bulus Raya No.49 Jakarta 12440 \\ ${ }^{2}$ Prodi Biologi FMIPA, Universitas Nusa Bangsa - Bogor \\ Jl. K.H.Soleh Iskandar Km. 4, Cimanggu, tanah Sereal - Bogor \\ *email : tretno@batan.go.id
}

\section{ABSTRACT \\ Quality Improvement of Liquid Organic Fertilizer from Water Waste of Biogas Using Compostar}

\begin{abstract}
It had been improved the quality of the liquid organic fertilizer from waste of Biogas production with the addition of inoculant $\left(F_{1}\right.$ and $\left.F_{2}\right)$ and without inoculant $\left(F_{0}\right)$ also additives $\left(V_{1}, V_{2}\right.$ and $\left.V_{3}\right)$. Variations of a given treatment comprised of $F_{0} V_{0}$ (as control), $F_{0} V_{l}, F_{0} V_{2}, F_{0} V_{3}, F_{1} V_{l}, F_{1} V_{2}, F_{1} V_{3}, F_{2} V_{1}, F_{2} V_{2}$ and $F_{2} V_{3}$ using experimental design of CRD (Completely Randomized Design) with $3 x$ replications . Liquid fertilizer quality parameters measured were : temperature, $p H$, organic- $C$, total- $N$ and $P$. While the parameters measured in the corn biomass is wet weight, dry weight, levels of $N$ and $P$. The results showed that the addition of biofertilizer Compostar isolates $\left(F_{2}\right)$ were able to decompose the form of additives to the maximum compared with $\left(F_{1}\right)$ and without $\left(F_{0}\right)$ the addition of commercial inoculant with an average content of $\mathrm{N}$ - total of $823.2 \mathrm{mg} / \mathrm{L}$ and the average $\mathrm{P}_{2} \mathrm{O}_{5}$ content of $187.7 \mathrm{mg} / \mathrm{L}$. While the addition of additives could increase levels of $\mathrm{N}$ - total and $\mathrm{P}_{2} \mathrm{O}_{5}$, where the levels of $\mathrm{N}$ - largest total in the treatment of $V_{3}$ ( Tp.fish Tp.bone $2 \%$ and $2 \%$ ) with an average of $967.6 \mathrm{mg} / \mathrm{L}$, while the largest concentration of $\mathrm{P}_{2} \mathrm{O}_{5}$ in treatment $V_{l}$ (Tp.fish $2 \%$ ) with an average of $154.4 \mathrm{mg} / \mathrm{L}$. Liquid organic fertilizer did not significantly affect the levels of nutrient uptake, biomass dry weight of corn plants, but had significant effect on plant height, stem large and heavy wet corn crop biomass, was the treatment of $F_{2} V_{2}$ with the addition of biofertilizer that isolates composter and additives in the form of bone meal $2 \%$.
\end{abstract}

Keywords : liquid organic fertilizer, biogas sludge, compostar

\begin{abstract}
ABSTRAK
Telah dilakukan peningkatan kualitas pupuk organik cair dari limbah produksi biogas dengan penambahan inokulan $\left(\mathrm{F}_{1}\right.$ dan $\left.\mathrm{F}_{2}\right)$ dan tanpa penambahan inokulan $\left(\mathrm{F}_{0}\right)$ serta penambahan zat aditif $\left(\mathrm{V}_{1}, \mathrm{~V}_{2}\right.$ dan $\mathrm{V}_{3}$ ). Variasi perlakuan yang diberikan terdiri dari $\mathrm{F}_{0} \mathrm{~V}_{0}$ sebagai kontrol, $\mathrm{F}_{0} \mathrm{~V}_{1}, \mathrm{~F}_{0} \mathrm{~V}_{2}, \mathrm{~F}_{0} \mathrm{~V}_{3}, \mathrm{~F}_{1} \mathrm{~V}_{1}$, $\mathrm{F}_{1} \mathrm{~V}_{2}, \mathrm{~F}_{1} \mathrm{~V}_{3}, \mathrm{~F}_{2} \mathrm{~V}_{1}, \mathrm{~F}_{2} \mathrm{~V}_{2}$, dan $\mathrm{F}_{2} \mathrm{~V}_{3}$ menggunakan rancangan percobaan RAL ( Rancang Acak Lengkap) dengan 3 x ulangan. Parameter kualitas pupuk cair yang diukur, yaitu : suhu, $\mathrm{pH}, \mathrm{C}$-organik, $\mathrm{N}$-total dan $\mathrm{P}$. Sedangkan parameter pada biomassa jagung yang diukur adalah bobot basah, bobot kering, Kadar hara $\mathrm{N}$ dan P. Hasil yang diperoleh menunjukkan bahwa penambahan biofertilizer berupa isolate Compostar $\left(\mathrm{F}_{2}\right)$ mampu menguraikan zat aditif secara maksimal dibandingkan dengan inokulan komersil $\left(\mathrm{F}_{1}\right)$ dan tanpa penambahan inokulan $\left(\mathrm{F}_{0}\right)$ dengan rataan kandungan $\mathrm{N}$-Total sebesar $823,2 \mathrm{mg} / \mathrm{L}$ dan rataan kandungan $\mathrm{P}_{2} \mathrm{O}_{5}$ sebesar $187,7 \mathrm{mg} / \mathrm{L}$. Sedangkan penambahan zat aditif mampu meningkatkan kadar N-Total dan $\mathrm{P}_{2} \mathrm{O}_{5}$, dimana kadar $\mathrm{N}$-Total terbesar pada perlakuan $\mathrm{V}_{3}$ ( Tp.ikan 2\% dan Tp.Tulang 2\%) dengan rataan sebesar $967,6 \mathrm{mg} / \mathrm{L}$, sedangkan kadar $\mathrm{P}_{2} \mathrm{O}_{5}$ terbesar pada perlakuan $\mathrm{V}_{1}$ (Tp.ikan 2\%) dengan rataan sebesar 154,4 $\mathrm{mg} / \mathrm{L}$. Pemberian pupuk organic cair tidak berpengaruh nyata terhadap serapan kadar hara, berat kering biomassa tanaman jagung, tetapi berpengaruh nyata terhadap tinggi tanaman,besar batang dan berat basah biomassa tanaman jagung, yakni pada perlakuan $\mathrm{F}_{2} \mathrm{~V}_{2}$ yaitu dengan penambahan biofertilizer isolate composter dan zat aditif berupa tepung tulang $2 \%$.
\end{abstract}

Kata Kunci : pupuk organik cair, sludge biogas, compostar. 


\section{PENDAHULUAN}

Bahan keluaran sisa proses pembuatan biogas yang berupa lumpur (sludge) dapat digunakan sebagai pupuk organik. Jenis pupuk dapat dibedakan menjadi dua jika dilihat berdasarkan sumber bahan yang digunakan yaitu pupuk organik dan pupuk anorganik. Pupuk anorganik adalah pupuk yang berasal dari bahan mineral yang telah diubah menjadi senyawa kimia yang mudah diserap tanaman. Sementara itu, pupuk organik adalah pupuk yang terbuat dari bahan organik atau makhluk hidup yang telah mati. Pupuk organik termasuk pupuk majemuk lengkap karena kandungan unsur haranya lebih dari satu unsur dan mengandung unsur mikro. Kandungan unsur hara dalam pupuk organik tidak terlalu tinggi bila dibandingkan dengan pupuk anorganik tetapi pupuk organik mempunyai keistimewaan lain yaitu dapat memperbaiki sifat fisik tanah, menggemburkan lapisan tanah permukaan (topsoil), meningkatkan jasad renik, serta meningkatkan daya serap dan daya simpan air sehingga secara keseluruhan dapat meningkatkan kesuburan tanah.

Pemanfaatan sludge sisa biogas sebagai pupuk dapat memberikan keuntungan yang hampir sama dengan penggunaan kompos. Sludge sisa biogas secara fisik berbentuk lumpur hitam dan tidak berbau, dan telah mengalami fermentasi anaerob sehingga dapat langsung digunakan untuk pemupukan. Pupuk yang dihasilkan dari limbah hasil pembuatan biogas adalah pupuk oganik karena bahan dasarnya merupakan limbah organik. Dilihat dari bentuknya, pupuk organik terbagi menjadi dua, yakni pupuk organik padat dan cair. Pupuk organik cair sendiri memiliki beberapa keuntungan daripada pupuk organik padat karena pengaplikasiannya lebih mudah, unsur hara yang terkandung di dalamnya lebih mudah diserap tanaman, dan mengandung mikroorganisme yang jarang terdapat dalam pupuk organik padat. Kandungan unsur hara dalam pupuk organik yang dihasilkan dari limbah hasil pembuatan biogas terbilang lengkap tetapi jumlahnya sedikit sehingga perlu ditingkatkan kualitasnya. Pembuatan pupuk cair relatip mudah dan biayanya cukup ekonomis (Hadisuwito, 2007).

Penelitian ini bertujuan memanfaatkan limbah cair dari produksi biogas sebagai bahan baku produksi pupuk organik cair serta mengetahui pengaruh penambahan bahan lain yang mengandung unsur hara makro seperti fosfor dan kalsium dan penambahan compostar produk Kelompok Lingkungan, Bidang Industri dan Lingkungan PAIR-BATAN yang mengandung mikroba penambat nitrogen dan pelarut fosfor yang digunakan pada tanaman uji yaitu jagung manis (Zea mays sp.).

\section{BAHAN DAN METODA}

\section{Bahan}

Bahan yang digunakan adalah sludge sisa biogas, dedak ,tepung ikan, tepung tulang, molases, Superfarm dan isolat mikroba Compostar koleksi dari Laboratorium kelompok Lingkungan Pusat Aplikasi Teknologi Isotop dan Radiasi- BATAN, Pasar Jum'at. Alatalat yang digunakan adalah jerigen, wadah penampungan/ember, plastik, saringan, karet, tali, kain saring, $\mathrm{pH}$ meter, termometer, gayung, corong, timbangan kapasitas $20 \mathrm{~kg}$, masker, sarung tangan karet, tali, kain saring, pHmeter, termometer dan gelas ukur.

\section{Metoda}

\section{Karakteristik pupuk cair Biogas}

Pemisahan sludge biogas padat dan cair dari outlet menggunakan saringan kawat dan ditempatkan ke tong plastik. Dilakukan analisis karakteristik awal $\left(\mathrm{H}_{0}\right)$. Untuk mengurangi kandungan metana $\left(\mathrm{CH}_{4}\right)$ dan gas-gas beracun lainnya $\left(\mathrm{H}_{2} \mathrm{~S}\right)$, pupuk organik cair tersebut distabilkan hingga hari ke-35 $\left(\mathrm{H}_{35}\right)$, kemudian dilakukan analisis. 
Fermentasi pupuk cair Biogas dengan Compostar

Untuk meningkatkan kualitasnya ditambahkan tepung tulang (2\%), tepung ikan (2\%), dedak, molasses dan penambahan masing- masing strain sebesar 0,5 dan $10 \mathrm{ml} / / \mathrm{L}$ pupuk organik cair $(1 \mathrm{ml}$ mengandung $10^{9}$ bakteri). Kondisi operasi yang dilakukan dengan nilai $\mathrm{pH}$ 6,5-7,5 dan suhu operasi $25-30{ }^{0} \mathrm{C}$. Fermentasi dilakukan selama 14 hari. Kemudian disaring lagi dengan saringan kelapa dan diaerasi selama $3-4$ hari, Kemudian dibiarkan selama 2 hari agar partikel-partikelnya mengendap. Pupuk cair yang diperoleh bewarna coklat seperti larutan air teh. Pada Tabel 1 menunjukkan perlakuan yang diberikan pada pupuk cair sludge biogas. Pada Gambar 1 ditunjukkan sampel pupuk cair dengan perlakuan tanpa tambahan inokulan $\left(\mathrm{F}_{0}\right)$ dan tambahan inokulan $\left(\begin{array}{lll}F_{1} & \text { dan } & F_{2}\end{array}\right)$ dengan $\mathrm{V}_{0}$ (tanpa tambahan nutrisi), $\mathrm{V}_{1}$ (tepung ikan), $\mathrm{V}_{2}$ (tepung tulang) dan $\mathrm{V}_{3}$ (tp.ikan + tp. Tulang).

\section{Analisa Kualitas Pupuk organik cair.}

Analisis dilakukan di laboratorium Kelompok Tanah PAIR-BATAN antara lain karakterisasi sludge sisa biogas sebelum $\left(\mathrm{H}_{0}\right)$ dan sesudah dilakukan fermentasi aerob $\left(\mathrm{H}_{35}\right)$, meliputi $\mathrm{pH}$, suhu, N-organik, C, rasio $\mathrm{C} / \mathrm{N}, \mathrm{P}, \mathrm{K}$, kandungan bakteri patogen. Sedangkan analisa kualitas pupuk cair biogas selama fermentasi 14 hari meliputi: $\mathrm{pH}$, suhu, $\mathrm{N}$-total dan $\mathrm{P}_{2} \mathrm{O}_{5}$.

\section{Aplikasi Pupuk Organik Cair pada Tanaman Uji (Jagung manis, Zea mays)}

Pengujian terhadap kualitas pupuk cair dilakukan pada tanaman jagung manis (Zea mays sp). Persiapan lahan tanam seluas $4 \times 6 \mathrm{~m}$ terbagi 4 plot dengan tanaman uji A (kontrol), tanaman $\mathrm{B}$ (tanpa inokulan, $\mathrm{F}_{0}$ ), tanaman $\mathrm{C}$ (inokulan $\mathrm{F}_{1}$ ) dan tanaman $\mathrm{D}$ (inokulan $F_{2}$ ). Dosis pemberian pupuk sebanyak satu kali/minggu. Pengamatan terhadap tanaman uji selama 35 hari setelah tanam (HST) meliputi: berat basah, berat kering, tinggi tanaman, besar batang, serapan $\mathrm{N}$ total dan serapan $\mathrm{P}_{2} \mathrm{O}_{5}$.

Tabel 1. Variasi Perlakuan

\begin{tabular}{l|l|l|l}
\hline Zat Aditif & \multicolumn{3}{|c}{ Inokulan } \\
\hline & $\mathrm{F}_{0}$ & $\mathrm{~F}_{1}$ & $\mathrm{~F}_{2}$ \\
\cline { 2 - 4 } Tanpa Tambahan $\left(\mathrm{V}_{0}\right)$ & $\mathrm{F}_{0} \mathrm{~V}_{0}$ & & \\
Tp. Ikan $(2 \%)\left(\mathrm{V}_{1}\right)$ & $\mathrm{F}_{0} \mathrm{~V}_{1}$ & $\mathrm{~F}_{1} \mathrm{~V}_{1}$ & $\mathrm{~F}_{2} \mathrm{~V}_{1}$ \\
$\begin{array}{l}\left.\text { Tp. Tulang (2\%) (V } \mathrm{V}_{2}\right) \\
\text { Tp. Ikan }(2 \%)+\text { Tp.Tulang(2\%) } \\
\left(\mathrm{V}_{3}\right)\end{array}$ & $\mathrm{F}_{0} \mathrm{~V}_{2}$ & $\mathrm{~F}_{1} \mathrm{~V}_{2}$ & $\mathrm{~F}_{2} \mathrm{~V}_{2}$ \\
\hline
\end{tabular}




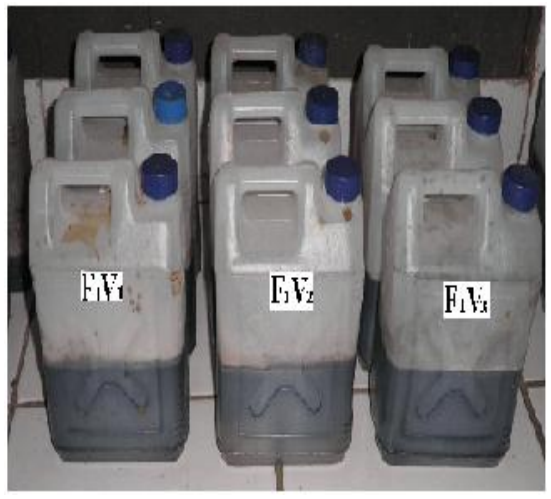

A

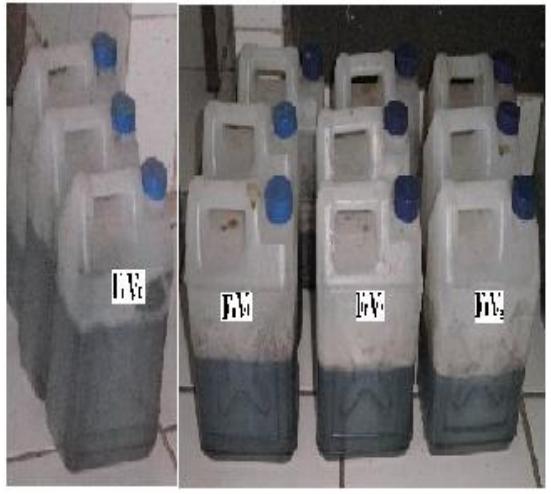

B

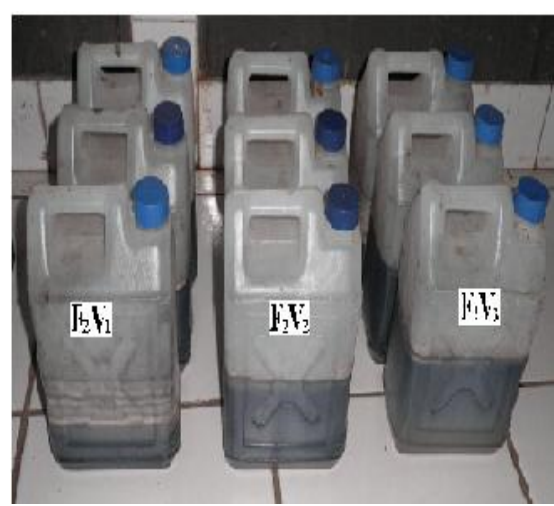

C

Gambar.1. A. Pupuk Organik Cair Tanpa Tambahan Inokulum $\mathrm{F}_{0} \mathrm{~V}_{0}, \mathrm{~F}_{0} \mathrm{~V}_{1}, \mathrm{~F}_{0} \mathrm{~V}_{2}$ dan $\mathrm{F}_{0} \mathrm{~V}_{3}$,

B. Pupuk Organik Cair Dengan Inokulum $F_{1} V_{1}, F_{1} V_{2}$ dan $F_{1} V_{3}$,

C. Pupuk Organik Cair Dengan Inokulum $\mathrm{F}_{2} \mathrm{~V}_{1}, \mathrm{~F}_{2} \mathrm{~V}_{2}$ dan $\mathrm{F}_{2} \mathrm{~V}_{3}$

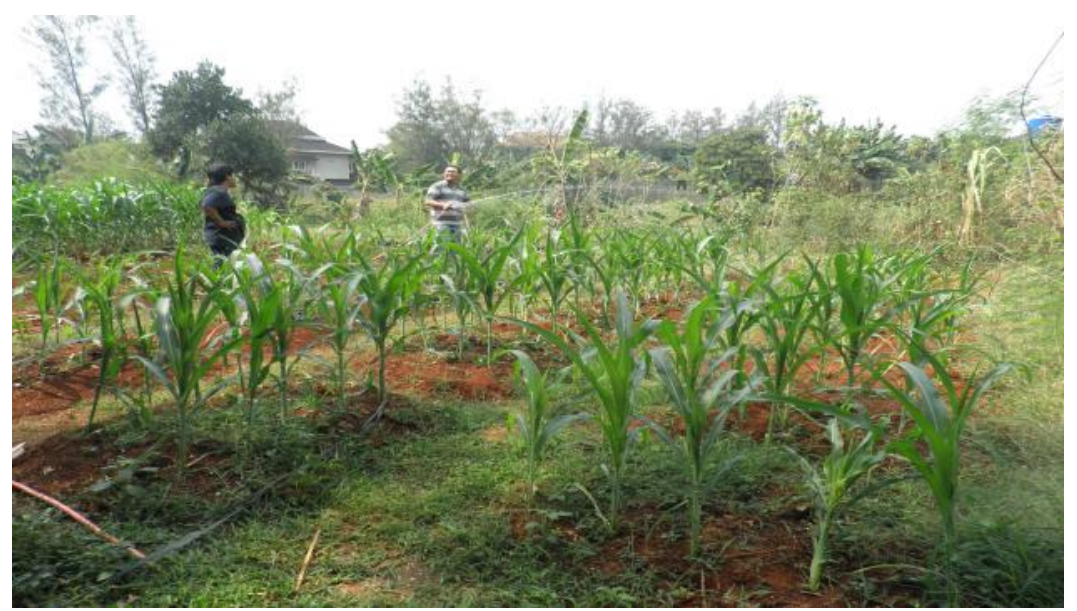

Gambar 2. Plot Tanaman Uji Jagung Manis 
HASIL DAN PEMBAHaSAN

\section{Karakterisasi Sludge Biogas}

Analisa sludge biogas dilakukan untuk mengetahui karakteristik kimia, fisika dan biologis sebelum dan sesudah fermentasi 35 hari menjadi pupuk organik cair. Pada Tabel 1 menunjukkan nilai $\mathrm{pH}$ sebelum dan sesudah fermentasi tidak mengalami perubahan. Hal itu dimungkinkan selama proses degradasi protein organik akan terbentuk $\mathrm{NH}_{3}$ yang akan berikatan dengan air membentuk $\mathrm{NH}_{4} \mathrm{OH}$ yang bersifat basa dan akan meningkatkan nilai $\mathrm{pH}$ di atas 8 (Widodo et.al., 2009). Suhu sludge sebelum dan sesudah fermentasi juga tidak berbeda jauh yakni kisaran 30 $31^{0} \mathrm{C}$.

Hal ini dapat diasumsikan bahwa bakteri yang aktif bekerja adalah jenis mesofilik. Sedangkan rasio $\mathrm{C} / \mathrm{N}$ sebelum fermentasi sebesar 30,37; sesudah fermentasi menurun menjadi 19,93. Hal ini menunjukkan adanya aktivitas mikroorganisme yang menggunakan karbon $(\mathrm{C})$ sebagai sumber energi dan meningkatkan kandungan nitrogen. Ini diperlihatkan pada kadar C- organik menurun sesudah fermentasi serta N-Total meningkat sesudah ferrnentasi . Nilai TS dan VS sebelum dan sesudah fermentasi mengalami penurunan. Ini menunjukkan adanya aktivitas mikroorganisme dalam mendegradasi bahan-bahan organik.

Tabel 2. Karakteristik Sludge Biogas

\begin{tabular}{c|c|c|c}
\hline \multirow{2}{*}{ Parameter } & \multirow{2}{*}{ Satuan } & \multicolumn{2}{|c}{ Sampel } \\
\cline { 3 - 4 } & & $\mathrm{H}_{0}$ & $\mathrm{H}_{35}$ \\
\hline Suhu & - & 31 & 30 \\
$\mathrm{pH}$ & - & 8 & 8 \\
Kadar Air & $\%$ & 93.36 & 95.20 \\
Kadar Abu & $\%$ & 11.12 & 1.20 \\
VS (Volatile & & & \\
Solid) & $\%$ & 5.90 & 3.60 \\
TS (Total Solid) & $\%$ & 6.64 & 4.80 \\
C-Organik & $\%$ & 44.66 & 29.90 \\
N-Total & $\%$ & 1.47 & 1.50 \\
C/N Rasio & - & 30.37 & 19.93 \\
& & Positif $(2400 /$ & \\
E.Coli & MPN & $100 \mathrm{ml})$ & Negatif \\
Salmonella & MPN & Negatif & Negatif \\
Coliform & MPN & Negatif & Negatif \\
\hline
\end{tabular}




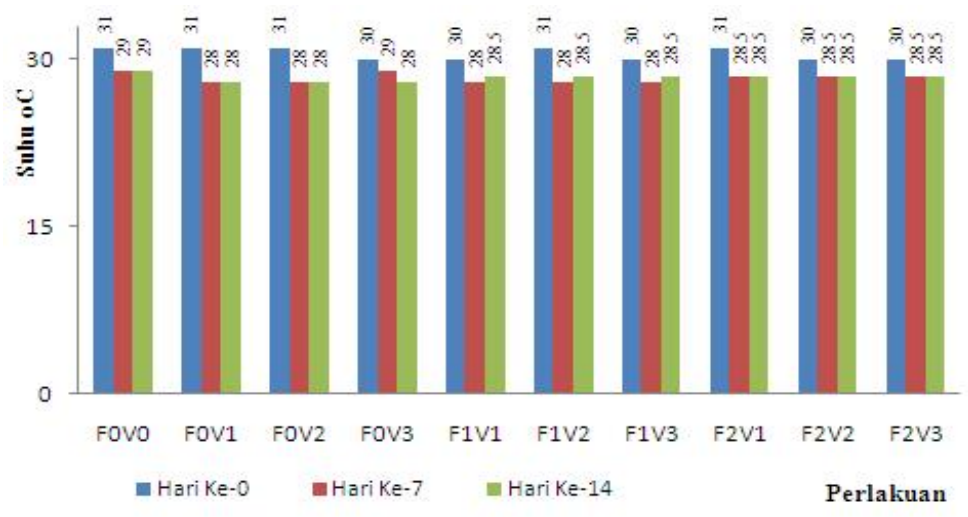

Gambar 3. Suhu Selama Fermentasi 14 Hari

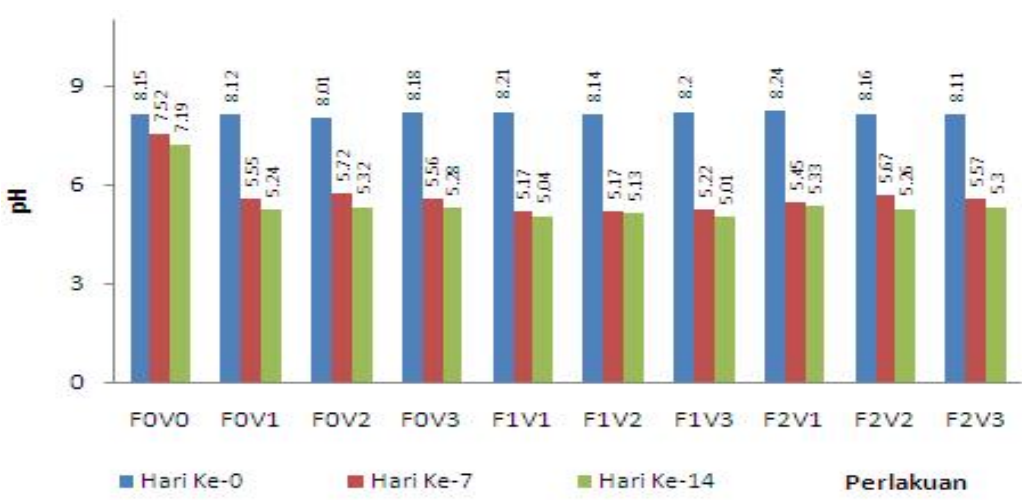

Gambar 4. Nilai pH Selama Fermentasi 14 Hari

Kadar air meningkat sesudah fermentasi, karena terbentuknya $\mathrm{OH}$ yang bersifat basa, sedangkan kadar abu menurun sesudah fermentasi. Analisis terhadap bakteri yang bersifat patogen menunjukkan bahwa sesudah fermentasi, baik E. coli, Salmonella dan Coliform negatif.

\section{Pengomposan Pupuk Cair}

Proses pengomposan merupakan proses dekomposisi bahan-bahan organik yang disebabkan adanya aktivitas mikroorganisme. Pada proses pengomposan akan berlangsung proses penguraian, pengikatan dan pembebasan berbagai zat atau unsur hara. Perubahan yang terjadi selama proses pengomposan dapat ditunjukkan dari parameter berikut.

\section{Suhu}

Selama proses pengomposan bahan organik cair, suhu ruangan berkisar $25^{\circ}-$ $28^{0} \mathrm{C}$ sedangkan suhu dalam reaktor berkisar $28,5^{\circ}-31^{\circ} \mathrm{C}$. Hal ini menunjukkan adanya aktivitas dekomposisi bahan organik oleh mikroorganisme yang meningkatkan suhu media cair bahan organik. Kisaran suhu $25^{0}-31^{\circ} \mathrm{C}$ ini sesuai dengan pertumbuhan bakteri jenis mesofilik yang dapat hidup pada suhu 15$45^{\circ} \mathrm{C}$, dengan tingkat pertumbuhan optimal pada suhu $25-35^{\circ} \mathrm{C}$ (Deacon, 1984).

\section{Nilai $\mathrm{pH}$}

Derajat keasaman media pengomposan mempengaruhi aktivitas mikroorganisme. Hasil yang diperoleh menunjukkan bahwa nilai $\mathrm{pH}$ berkisar 5,01 $-8,36$. Ini sesuai dengan kisaran nilai $\mathrm{pH}$ yang diperoleh oleh Yang (1997) yakni 
berkisar 5,5 - 8,0. Pada proses fermentasi, bakteri asidogenik akan beraktivitas dalam mendegradasi limbah organik dan menghasilkan asam-asam organik. Akumulasi asam akan terjadi karena konsentrasi asam volátil yang tinggi sehingga menurunkan nilai $\mathrm{pH}$.

\section{Kualitas Pupuk Cair}

\section{Kadar N-Total}

Unsur $\mathrm{N}$ merupakan hara esensial yang dibutuhkan tanaman dalam jumlah yang banyak. Pada Gambar.5 ditunjukkan bahwa rataan kandungan N-Total pupuk organik cair yaitu $760,3 \mathrm{mg} / \mathrm{L}$ lebih tinggi dibandingkan pupuk cair kontrol sebesar 201,7 mg/L. Kandungan $\mathrm{N}$-Total pupuk cair dengan penambahan zar aditif dan isolate Compostar sebesar $823,2 \mathrm{mg} / \mathrm{L}$ lebih tinggi dari pupuk cair dengan penambahan zat aditif dan inokulan komersil(Superfarm) sebesar $783,3 \mathrm{mg} / \mathrm{L}$. Penambahan zat hara dan inokulan mikroba dapat meningkatkan kadar N-total pada pupuk cair sisa produksi biogas.

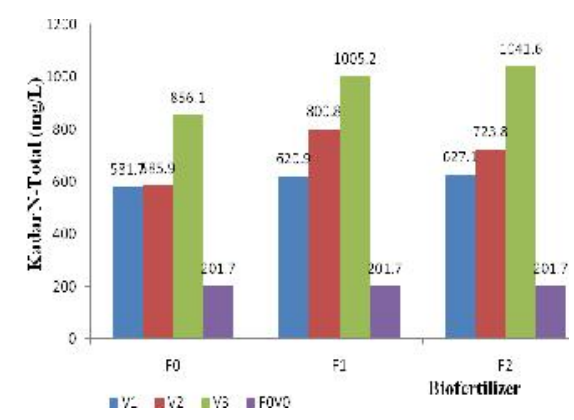

Gambar 5. Kadar N-total pada Pupuk Cair

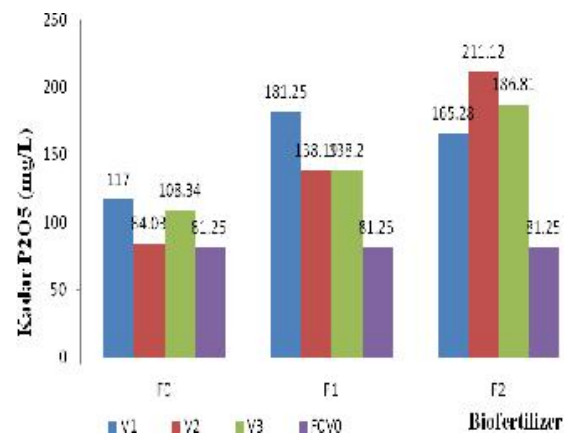

Gambar 6. Kadar $\mathrm{P}_{2} \mathrm{O}_{5}$ pada Pupuk Cair

\section{Kadar $\mathrm{P}_{2} \mathrm{O}_{5}$}

Pada Gambar.6 menunjukkan bahwa rataan kandungan $\mathrm{P}_{2} \mathrm{O}_{5}$ pupuk organik cair yaitu 147,8 mg/L lebih tinggi dibandingkan pupuk cair kontrol sebesar 81,2 $\mathrm{mg} / \mathrm{L}$. Kandungan $\mathrm{P}_{2} \mathrm{O}_{5}$ pupuk cair dengan penambahan zar aditif dan inokulan Compostar sebesar 187,7 mg/L lebih tinggi dari pupuk cair dengan penambahan zat aditif dan inokulan komersil (Superfarm) sebesar 152,5 $\mathrm{mg} / \mathrm{L}$. Penambahan zat hara dan inokulan mikroba dapat meningkatkan kadar $\mathrm{P}_{2} \mathrm{O}_{5}$ pada pupuk cair sisa produksi biogas.

\section{Pengaruh Pupuk Cair Terhadap Tanaman Jagung manis (Zea mays sp)}

\section{Bobot Basah dan Bobot Kering}

Pada Gambar 7. ditunjukkan pengaruh pemberian pupuk organik cair terhadap bobot basah dan bobot kering tanaman jagung manis pada 35 HST. Bobot basah tanaman D2 sebesar 139,3 gram dan bobot keringnya sebesar 36,7 gr. Hal ini mengindikasikan bahwa pupuk cair variasi $\mathrm{F}_{2} \mathrm{~V}_{2}$, yakni penambahan inokulan Compostar dan tepung merupakan kombinasi yang memberikan kemampuan penyediaan air dan nutrisi yang tinggi, sehingga memberikan bobot basah tertinggi. Bobot kering tanaman merupakan hasil dari tiga proses, yaitu penumpukan asimilat melalui fotosintesa, penurunan asimilat akibat respirasi dan akumulasi ke bagian cadangan makanan (Parman, 2007). Berat kering tumbuhan 
adalah keseimbangan antara pengambilan $\mathrm{CO}_{2}$ (fotosíntesis) dan pengeluaran $\mathrm{CO}_{2}$ (respirasi). Apabila respirasi lebih besar dibanding fotosíntesis, maka berat kering tumbuhan akan berkurang.

\section{Kadar Serapan Hara Tanaman jagung Manis pada 35 HST.}

Unsur hara makro $\mathrm{N}$ dan $\mathrm{P}$ merupakan zat esensil pada pertumbuhan tanaman. Pada Gambar 8. ditunjukkan pengaruh pemberian pupuk organik cair terhadap serapan N-total dan $\mathrm{P}_{2} \mathrm{O}_{5}$ tanaman jagung manis pada 35 HST. Hasil yang diperoleh menunjukkan bahwa variasi perlakuan yang diberikan tidak memberikan pengaruh yang nyata terhadap serapan kadar N-total maupun $\mathrm{P}_{2} \mathrm{O}_{5}$ pada tanaman Jagung manis.

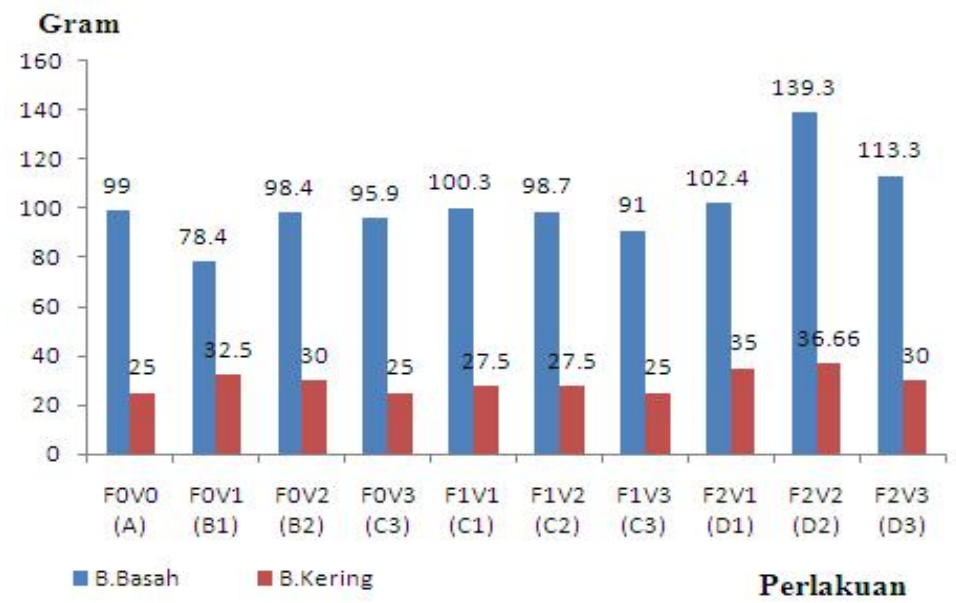

Gambar 7. Bobot Basah dan Kering Tanaman Jagung Manis pada 35 HST

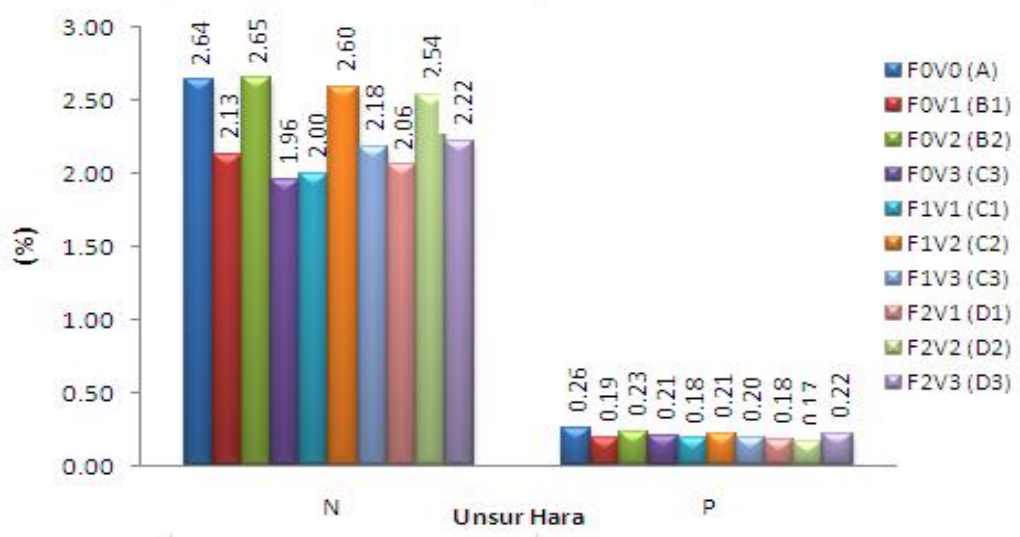

Gambar 8. Serapan N-total dan Serapan $\mathrm{P}_{2} \mathrm{O}_{5}$ Tanaman Jagung Manis Pada 35 HST 


\section{Tinggi (cm)}

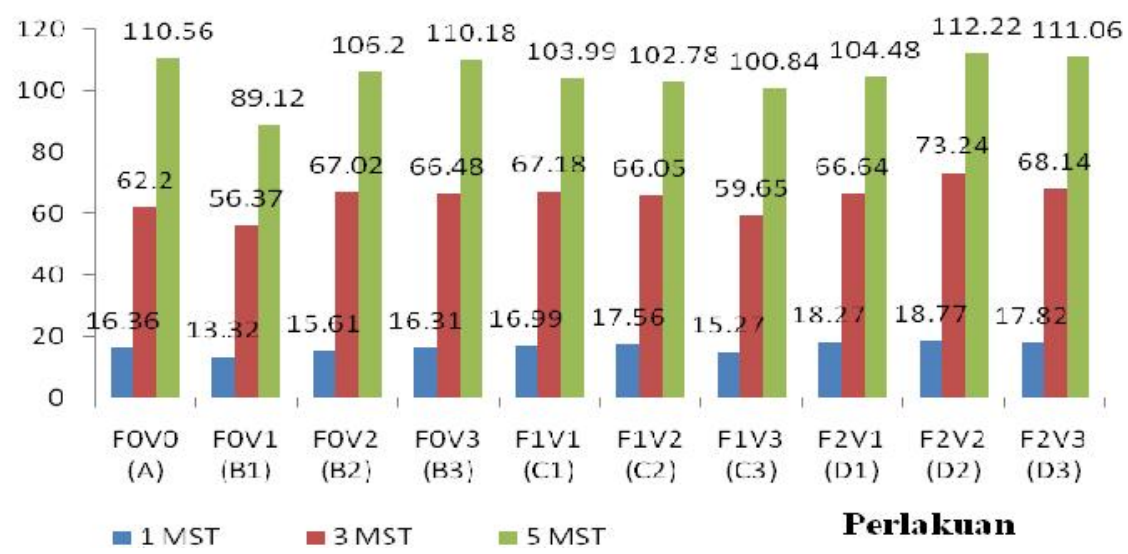

Gambar 9. Tinggi Tanaman Jagung Manis Sampai 35 HST

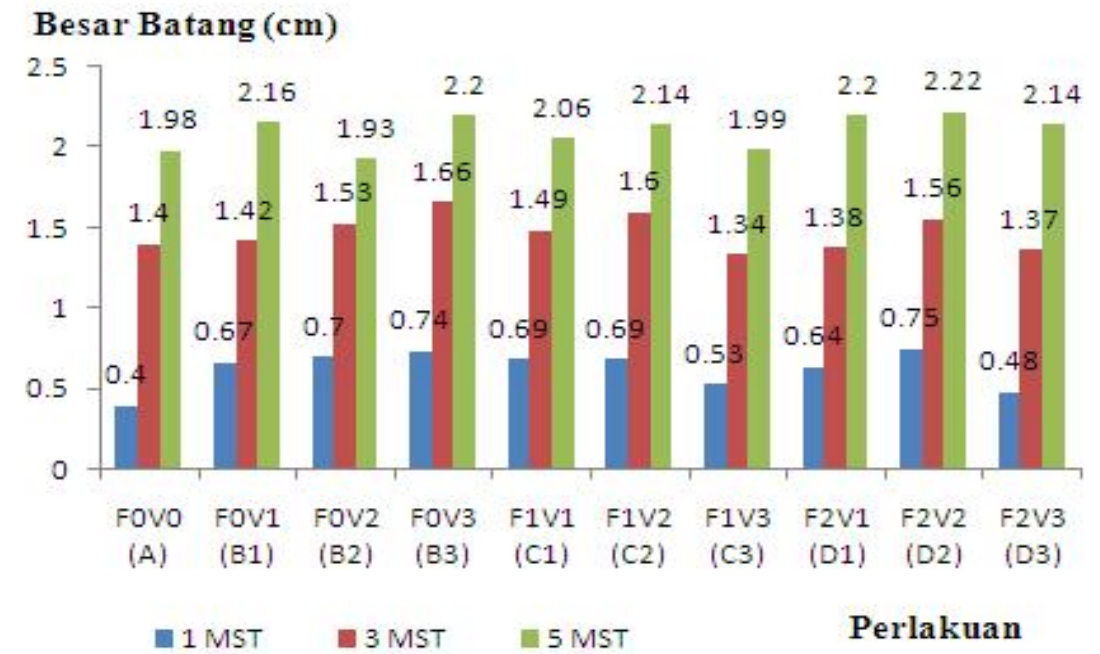

Gambar 10. Besar Batang Jagung Manis Sampai 35 HST

\section{Tinggi Tanaman pada 35 HST}

Pada Gambar. 9 ditunjukkan pengaruh pupuk cair pada pertumbuhan tinggi tanaman jagung manis pada 7 HST, 21 HST dan 35 HST. Tanaman jagung manis (Zea mays sp) D2 pada 35 HST dengan tinggi $112,22 \mathrm{~cm}$ merupakan tinggi optimal. Pemberian pupuk cair $\mathrm{F}_{2} \mathrm{~V}_{2}$ menunjukkan pengaruh pada tinggi tanaman jagung manis D2, karena pertumbuhan tinggi tanaman pada 7 HST, 21 HST dan 35 HST memberikan pertambahan tinggi yang signifikan.

\section{Besar Batang Tanaman pada 35 HST}

Pada gambar.10 ditunjukkan pengaruh pupuk cair terhadap besar batang tanaman jagung manis pada 7 HST, 21 HST dan 35 HST. Perlakuan yang terbaik adalah $\mathrm{F}_{2} \mathrm{~V}_{2}$ yang menun-jukkan setiap masa setelah tanam mem-perlihatkan peningkatan tinggi tanaman yang signifikan. Tanaman jagung manis D2 dengan besar batang $2,22 \mathrm{~cm}$ pada 35 HST merupakan besar batang yang optimum. 


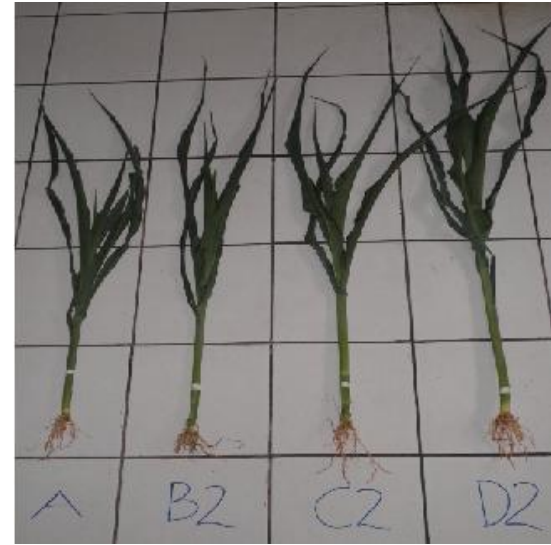

(a)

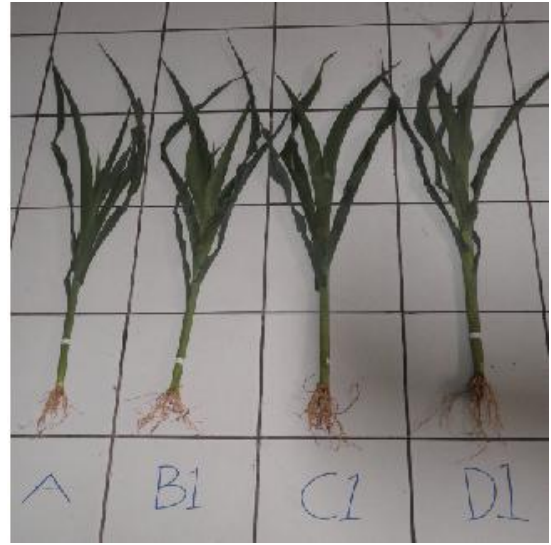

(b)

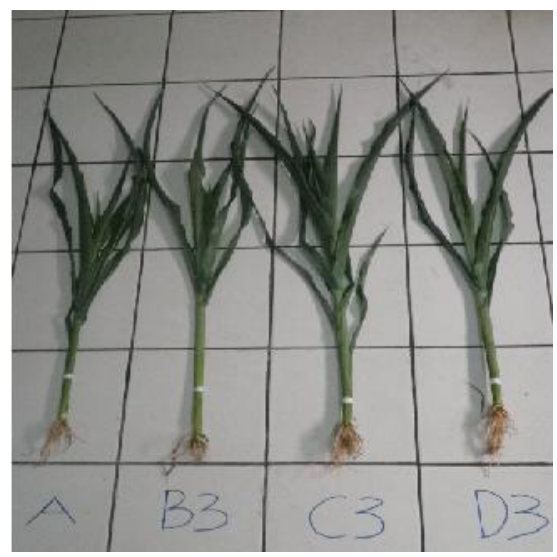

(c)

Gambar 11. (a). Tinggi dan besar Tanaman Jagung Kontrol (A) dan penambahan Tp.ikan (1) serta tanpa inokulan (B), inokulan komersil (C) serta inokulan Compostar (D)

(b). Tinggi dan besar Tanaman Jagung Kontrol (A) dan penambahan Tp.tulang (2) serta tanpa inokulan (B), inokulan komersil (C) serta inokulan Compostar (D)

(c). Tinggi dan besar Tanaman Jagung Kontrol (A) dan penambahan Tp.ikan + Tp.Tulang (3) serta tanpa inokulan (B), inokulan komersil (C) serta inokulan Compostar (D)

Pada Gambar 11a, 11b dan 11c ditunjukkan tinggi dan besar tanaman jagung manis pada 35 HST dengan variasi perlakuan yang diberikan. Pada Gambar $11 \mathrm{a}, 11 \mathrm{~b}$ dan $11 \mathrm{c}$ tersebut menunjukkan bahwa tinggi dan besar batang .pada tanaman jagung manis diberikan inokulan Compostar (D1, D2 dan D3) mencapai pertumbuhan optimal. Serabut akar pada tanaman jagung manis D1, D2 dan D3 tampak lebih panjang dan lebih banyak dibandingkan dengan tanaman jagung lainnya. Hal itu disebabkan karena inokulan di dalam Compostar merupakan Inoculant Microbes Rhizosphere ( IMR), yakni kelompok mikroba tanah yang hidup di sekitar perakaran, diantaranya bakteri Bacillus sp, Azotobacter sp dan bakteri Rhizobium.

\section{KESIMPULAN}

Penambahan inokulan berupa isolate Compostar mampu menguraikan zat aditif secara maksimal dibandingkan dengan EM komersil dan tanpa penambahan EM (mikroba ruminansia) dengan rataan kandungan N-Total sebesar 823,2 mg/L dan rataan kandungan $\mathrm{P}_{2} \mathrm{O}_{5}$ sebesar 187,7 $\mathrm{mg} / \mathrm{L}$.

Penambahan zat aditif mampu meningkatkan kadar N-Total dan $\mathrm{P}_{2} \mathrm{O}_{5}$, dimana kadar N-Total terbesar pada perlakuan $\mathrm{V}_{3}$ ( Tp.ikan $2 \%$ dan Tp.Tulang $2 \%$ ) dengan rataan sebesar 967,6 mg/L, sedangkan kadar $\mathrm{P}_{2} \mathrm{O}_{5}$ terbesar pada 
perlakuan $\mathrm{V}_{1}$ (Tp.ikan 2\%) dengan rataan sebesar $154,4 \mathrm{mg} / \mathrm{L}$.

Pemberian pupuk organik cair tidak berpengaruh nyata terhadap serapan kadar hara, berat kering biomassa tanaman jagung, tetapi berpengaruh nyata terhadap tinggi tanaman, besar batang dan berat basah biomassa tanaman jagung, yakni pada perlakuan $\mathrm{F}_{2} \mathrm{~V}_{2}$ yaitu dengan penambahan $\mathrm{r}$ isolate compostar dan zat aditif berupa tepung tulang $2 \%$.

\section{UCAPAN TERIMA KASIH}

Penulis mengucapkan terima kasih kepada Bapak Marwadi dan Saudara Andri Musa yang telah membantu di teknis lapang penelitian ini.

\section{DAFTAR PUSTAKA}

Deacon, JW. 1984. Introduction to Modern Mycology.Blackwell Scientific Publication. London

Hadisuwito, S. 2007. 'Membuat Pupuk Kompos dan Cair'. Agromedia Pustaka, Jakarta.

Widodo, W. T, et.al. 2009 Design and development of biogas reactor for farmer group scale. Indonesia Journal of Agriculture. Tangerang 121-128.

Yang, S. S. 1997. Preparation of compost and evaluating it's maturity. Agriculture and Holticulture Extension Bulletin No.44 